\title{
OTOMATISASI PROSES PRODUKSI CAT BERBASIS SIMULATOR PLC TWIDO TWDLMDA20DTK
}

\author{
Fahmizal $^{1}$, Donny Budi Pratama ${ }^{2}$, Angga Priyatmoko $^{3}$, M Riza Fauzi Rahman $^{4}$ \\ 1,2,3,4 Departemen Teknik Elektro dan Informatika, Sekolah Vokasi, Universitas Gadjah Mada \\ Yogyakarta, Indonesia
}

e-mail: fahmizal@ugm.ac.id, donny.budi.p@mail.ugm.ac.id, angga.priyatmoko@mail.ugm.ac.id,m.riza.f@mail.ugm.ac.id

\begin{abstract}
Abstrak
Makalah ini bertujuan untuk mensimulasikan implementasi programmable logic controller (PLC) pada mesin otomatisasi produksi cat. Makalah ini pada dasarnya menyajikan proses otomatisasi produksi cat. Secara garis besar, terdapat tiga proses utama yaitu, proses produksi adonan cat, proses pengisian cat dalam kaleng kemasan, dan proses pengepakan kaleng cat ke dalam box. Pada makalah ini, simulasi sistem otomasi produksi cat menggunakan software Twido Suite TWDLMDA20DTK. Simulasi bertujuan untuk meminimalkan kesalahan dalam merancang sistem sehingga dapat menghemat waktu. Hasil yang diperoleh dari simulasi bahwa sistem telah berjalan berjalan dengan baik dan sesuai dengan seharusnya.
\end{abstract}

Kata kunci: PLC, Twido, otomatisasi.

\begin{abstract}
This paper intends to simulate the implementation of the programmable logic controller (PLC) on paint production automation machines. This paper basically presents the process of automating paint production. In general, there are three main processes namely, the process of paint dough production, the process of filling paint in packaging cans, and the process of packing paint cans into the box. In this paper. simulation of paint production automation system using Twido Suite TWDLMDA20DTK software. Simulation intends to minimize error to bulit the system operating time. The results obtained from the simulation that the system has been running well.
\end{abstract}

Keywords : PLC, Twido, Automation.

\section{PENDAHULUAN}

Penggunaan programmable logic controller (PLC) di industri bertujuan untuk mempermudah pengontrolan yang dilakukan pada mesin-mesin di industri. Kehadiran PLC sangat dibutuhkan terutama untuk menggantikan sistem pengkabelan yang digunakan dalam mengendalikan suatu sistem (Ramadhan, 2014). Pada masa lalu, setiap perangkat elektronik harus dikendalikan oleh pengendalinya masing-masing, hal tersebut sangat tidak efektif karena jika terdapat sepuluh mesin maka terdapat sepuluh kontroler untuk mengontrolnya. Sedangkan jika menggunakan PLC maka sepuluh mesin tersebut dapat dikendalikan dengan hanya menggunakan sebuah kontroler saja (Bolton, 2004).
Salah satu industri yang sangat dibutuhkan manusia adalah industri produksi cat. Hal tersebut selain melihat kebutuhan pembangunan suatu infrastruktur gedung yang makin hari semakin berkembang dan bertambah. Untuk melakukan proses produksi cat dibutuhkan proses yang cukup panjang dan berulang - ulang sehingga diperlukan konsentrasi yang tinggi dalam pembuatannya. Dalam hal ini, peran PLC sangat dibutuhkan. Terlepas dari alasan tersebut penggunaan PLC juga untuk memenuhi produksi cat sendiri yang setiap tahunnya mengalami peningkatan. Dalam makalah ini akan dijelaskan bagaimana penggunaan PLC pada produksi cat berbasis PLC Twido TWDLMDA20DTK. 
Kebutuhan akan produksi cat dengan tingkat efisiensi dan efektifitas dari proses pengerjaan dan hasil yang tinggi pada suatu proses produksi, terutama pada produksi massal sangatlah penting, karena dapat menghemat waktu dan biaya, sehingga ongkos produksi yang dikeluarkanpun akan dapat sekecil mungkin. Suatu mesin yang digunakan untuk membuat cat telah banyak beredar dipasaran, namun alat yang bersifat otomatis masih belum banyak, sehingga dalam hal ini penulis mencoba untuk menjelaskan suatu mesin untuk menyelesaikan dan memberi solusi terhadapa masalah, dimana diharapkan sistem otomasi ini mampu memaksimalkan efisiensi guna meningkatkan efektifitas yang lebih baik.

\section{TINJAUAN PUSTAKA}

\section{Programmable Logic Controller (PLC)}

PLC merupakan sebuah komputer elektronik yang merupakan salah satu produk dari perkembangan teknologi di bidang teknik kendali (Antono, 2012). PLC bisa juga didefinisikan sebagai sebuah sistem elektronik yang beroperasi secara digital dan banyak dari padanya di desain untuk linkungan industri. PLC memiliki sistem penyimpanan yang beguna untuk menyimpan data-data perhitungan/fungsifungsi spesifik seperti logika, urutan, perwaktuan (timer), atau operasi aritmatik yang banyak digunakan untuk mengontrol mesin-mesin atau proses industri melalui modul dengan I/O digital maupun analog (O.Boucher, 2012). Dari istilah yang ada (Programmable Logic Controller), PLC memiliki arti tersendiri didalamnya. Berikut penjabarannya;

\section{Programmable}

Programmable

menunjukan

kemampuan dari PLC dalam hal storage (penyimpanan). Dalam hal penyimpanan PLC bisa menyimpan program yang telah dibuat dan program yang telah disimpan masih bisa diubah fungsi dan kegunaanya (Janotha, 2014).

\section{Logic}

Logic menunjukan kemampuan PLC dalam mengolah masukan secara aritmatik dan logis atau biasa disebut Arithmetic Logical Unit (ALU) (Herlan, 2015). Dalam fungsinya sebagai ALU, PLC bisa melakukan operasi aritmatik seperti membandingkan, pengurangan, penjumlahan, perkalian, negasi, dan sebagainya.

\section{Controller}

Controller menunjukan kemampuan PLC dala mengolah input yang bisa dikontrol secara manual maupun otomatis oleh operator sehingga menghasilkan keluaran yang diinginkan (Setiawan, 2006).

Pada dasarnya PLC dirancang untuk menggantikan suatu rangkaian relay sequensial dalam suatu sistem kontrol. PLC memiliki bahasa sendiri yang mudah untuk diartikan oleh pengguna, tergantung jenis PLC yang digunakan maka bahasa pemrogramannya pun akan berbeda. Keluaran pada PLC bisa berupa logika atau angka 1 dan 0 yang berarti $1(O N)$ dan 0 (OFF). Tidak hanya satu keluaran, PLC juga dapat diterpakan pada sistem dengan keluaran yang banyak. PLC memiliki beberapa fungsi yang dapat diaplikasikan dalam pengendalian. Berikut fungsi umum dari PLC;

\section{Sekuensial Kontrol}

PLC memiliki fungsi sekuensil kontrol, fungsi sekuensial kontrol merupakan fungsi dimana PLC bekerja sebagai pengolah masukan biner menjadi keluaran yang dibutuhkan oleh sebuah teknik pemrosesan yang berlangsung secara berurutan (sekuensial). PLC pada proses ini juga berfungsi sebagai pengontrol setiap step dari proses agar semuanya berjalan secara berurutan (Johnson, 2007).

\section{Monitoring Plant}

Monitoring Plant merupakan salah satu fungsi PLC yang berfungsi untuk memonitor suatu sistem yang harus diberikan perlakuan khusus seperti temperatur, tekanan, tingkat ketinggian, keasaman, dan sebagainya (Barrett, 2008). 
PLC juga akan berfungi untuk pengambilan tindakan apabila ada proses yang melebihi batas. PLC akan memberikan tindakan pencegahan dan pengurangan pada sistem tersebut.

\section{TwidoSuite TWDLMDA20DTK}

Twido Suite adalah software untuk memprogram PLC yang dibuat oleh Schneider Telemecanique dengan tampilan seperti pada Gambar 1 (Ardiansyah, Taryana, \& Nataliana, 2013). Software ini dapat digunakan untuk memprogram semua tipe PLC Twido Compact (TWDLCAA10DRF, dll) dan Modular (TWDLMDA40DTK, dII) (Schneider, 2006). Pada paper ini menggunakan PLC Twido tipe TWDLMDA20DTK .

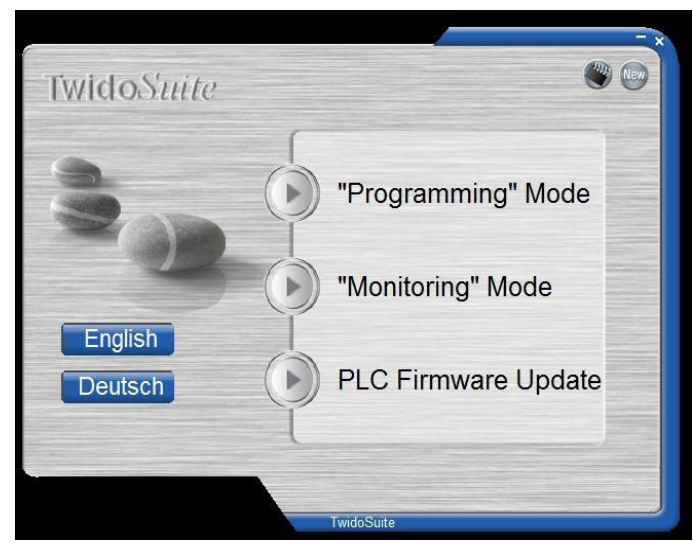

Gambar 1. Twido suite V2.30

\section{METODE}

Secara garis besar, otomasi proses produksi cat dibagi menjadi tiga proses yaitu proses pembuatan adonan cat, pengisian cat dalam kaleng kemasan, dan pengepakan kaleng kemasan ke dalam box. Untuk ilustrasi gambran otomasi proses produksi cat dapat dilihat pada Gambar 3.

\section{Pembuatan Adonan Cat}

Pada proses pembuatan cat, perlu diperhatikan bahan-bahan yang diperlukan untuk membuat cat itu sendiri (Nurseto, 2011). Dalam kasus ini hanya dibutuhkan air dan konsentrat cat sebagai pewarna saja. Pada Gambar 3 pompa A dan pompa $B$ berfungsi sebagai pengisi air pada tangki dan konveyor A membawa konsentrat cat untuk membuat adonan cat. Saat bahan- bahan yang diperlukan sudah mengisi tangki, untuk mencampurkan adonan cat diperlukan proses pengadukan dengan mixer agar adonan cat dapat tercampur dengan baik. Pada tangki cat terdapat dua buah sensor yang terpasang di bagian bawah tangki dan di bagian atas tangki untuk mengetahui berapa banyak volume adonan cat yang terisi dalam tangki.

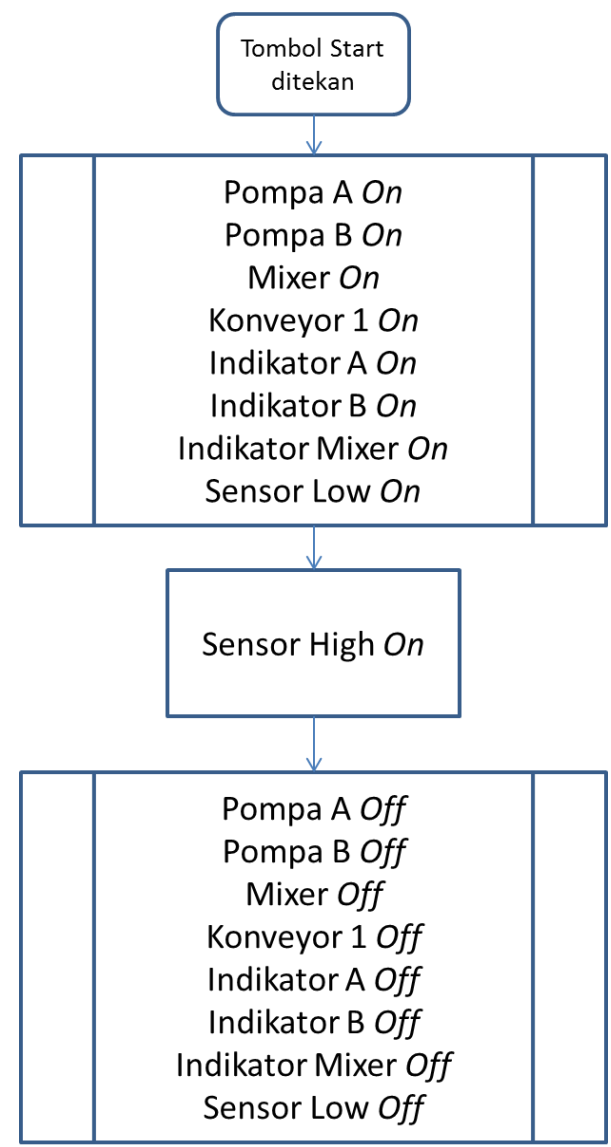

\section{Gambar 2. Blok Diagram Proses Pembuatan Adonan Cat}

Pada Gambar 3 disajikan beberapa komponen yang digunakan sebagai masukan dan keluaran, yaitu tombol start, pompa $\mathrm{A}$, pompa $\mathrm{B}$, konveyor $\mathrm{A}$, mixer, dan sensor. Pada pompa $A$, pompa $B$, konveyor A, dan mixer terdapat lampu indikator yang berfungsi sebagai penanda bahwa alat ini dalam keadaan aktif atau mati. Pada sistem ini, sensor yang berada di bagian bawah tangki akan dinamakan sebagai LOW, dan sensor yang berada di bagian atas tangki akan dinamakan $\mathrm{HIGH}$. 


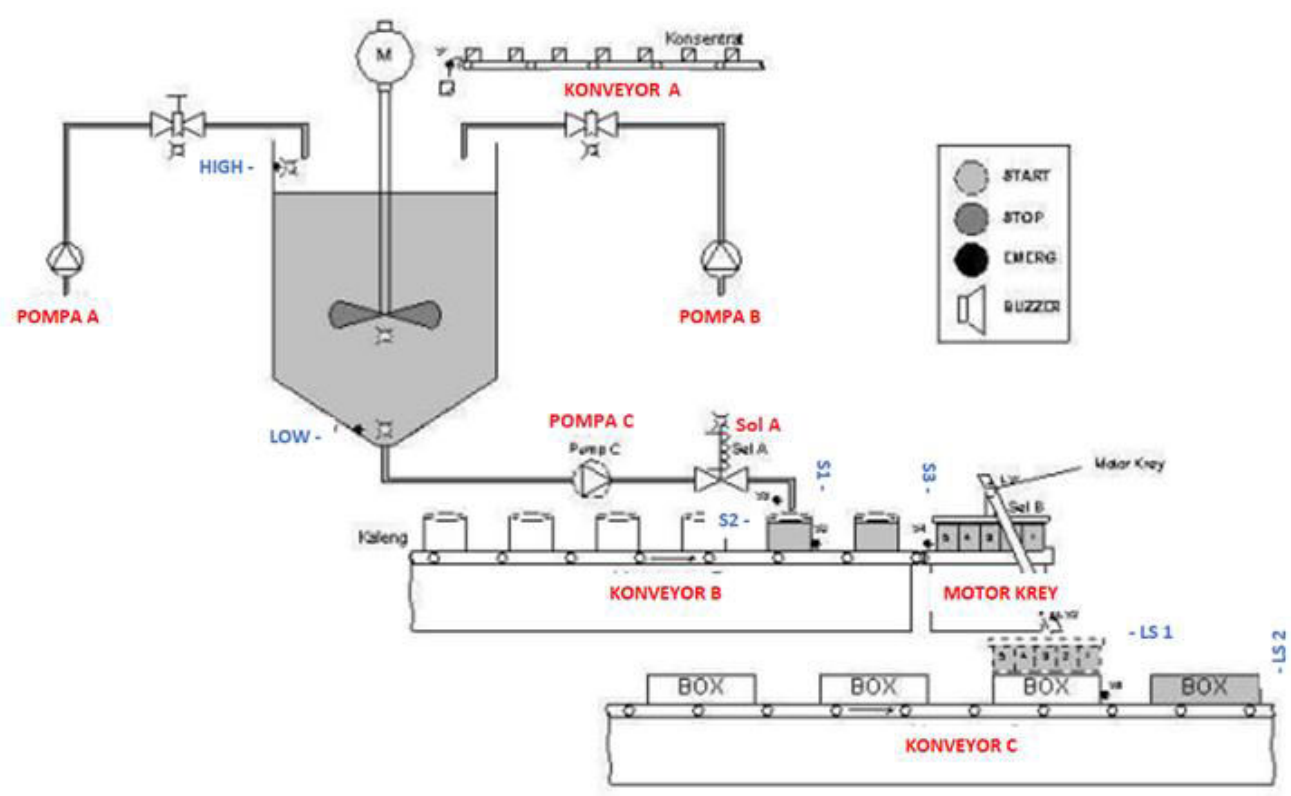

Gambar 3. Proses Otomatisasi Produksi Cat

Menurut pada blok diagram Gambar 2 proses pembuatan adonan cat dan juga untuk mengaktifkan seluruh sistem otomatisasi proses produksi cat akan dimulai dengan menekan tombol start. Setelah itu pompa A dan pompa B beserta lampu indikatornya akan aktif dan mulai mengisikan air pada tangki. Konveyor A beserta lampu indikatornya juga akan aktif dan menjatuhkan konsentrat cat pada tangki. Mixer akan aktif dan bertugas untuk mengaduk adonan cat yang berisi air dan konsentrat cat di dalam tangki.

Saat adonan cat mulai mengisi tangki, maka sensor LOW akan mendeteksi adanya cairan yang mengenai sensor yang berarti terdapat sejumlah volume adonan di dalam tangki. Ketika tangki penuh ditandai oleh aktifnya sensor HIGH. Selanjutnya, ketika sensor HIGH aktif maka pompa A, pompa $\mathrm{B}$, konveyor $\mathrm{A}$ dan mixer akan mati. Proses ini dapat digambarkan menggunakan timing digram seperti pada Gambar 6.

\section{Proses Pengisian Cat dalam kaleng}

Setelah tangki cat telah penuh terisi cairan cat, selanjutnya proses pengisian cat kedalam kaleng cat. Pada proses ini, ada beberapa aktuator dan sensor yang bekerja, yaitu, pompa C, konveyor B, solenoid $A$, indikator solenoid $A$, sensor 1 dan sensor 2 .

Pada proses ini, ketika tangki cat sudah penuh yang ditandai dengan aktifnya sensor $\mathrm{HIGH}$, maka pompa $\mathrm{C}$ akan aktif dan mengalirkan cat dari tangki. Namun cat akan ditahan oleh sol A karena sol A hanya akan bekerja ketika sensor 1 aktif. Konveyor B aktif saat sol A mati untuk membawa kaleng cat hingga menghalangi sensor 1 dan mengaktifkannya. Lalu sol A aktif dan bekerja untuk menyedot cat dan mengisikannya pada kaleng hingga kaleng tersebut penuh yang ditandai dengan aktifnya sensor 2 . Setelah itu konveyor B akan aktif lagi untuk membawa kaleng cat menuju motor krey.

Seperti pada blok diagram Gambar 4, pertama, pompa $C$ akan aktif untuk mengalirkan cat dari tangki. Konveyor B akan aktif untuk membawa kaleng cat hingga ada kaleng yang menghalangi sensor 1. Ketika sensor 1 mendeteksi adanya kaleng cat, konveyor B akan mati. Setelah itu, solenoid A akan aktif untuk mengisikan cat pada kaleng. Saat sensor 2 aktif, menandakan bahwa kaleng sudah terisi penuh dengan cat. Saat kaleng cat sudah penuh, solenoid $A$ akan mati, dan konveyor B akan aktif untuk membawa kaleng menuju falling edge motor krey. 


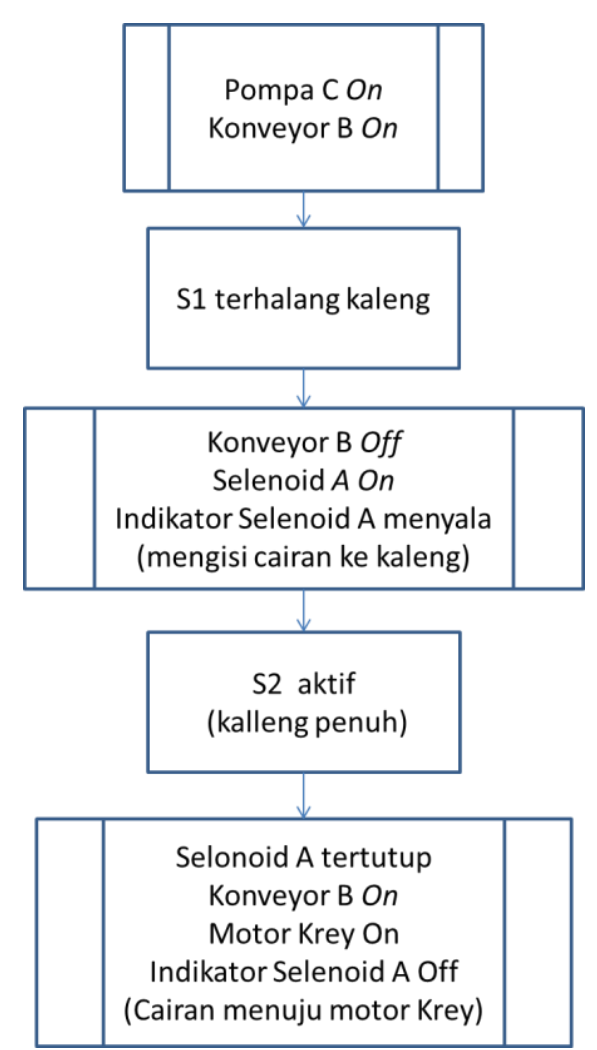

Gambar 4. Blok Diagram Proses Pengisian Cat dalam kaleng

Gambar 7 merupakan timing diagram dari blok diagram Gambar 4 yang menggambarkan alur kerja dari setiap aktuator dan sensor pada proses pengisian cat dalam kaleng cat.

\section{Proses Pengepakan Kaleng Kemasan ke dalam Box}

Setelah kaleng cat sudah terisi dengan cat, selanjutnya kaleng-kaleng kemasan tersebut akan di packing ke dalam box. Setiap box akan diisi oleh beberapa kaleng kemasan sesuai dengan kebutuhan dan kehendak produsen.

Pada step ini, ada beberapa sensor dan aktuator yang bekerja, yaitu, sensor 3, sensor LS1, sensor LS2, motor krey, dan konveyor C. Gambaran proses pada step ini dapat dilihat pada blok diagram Gambar 5 .

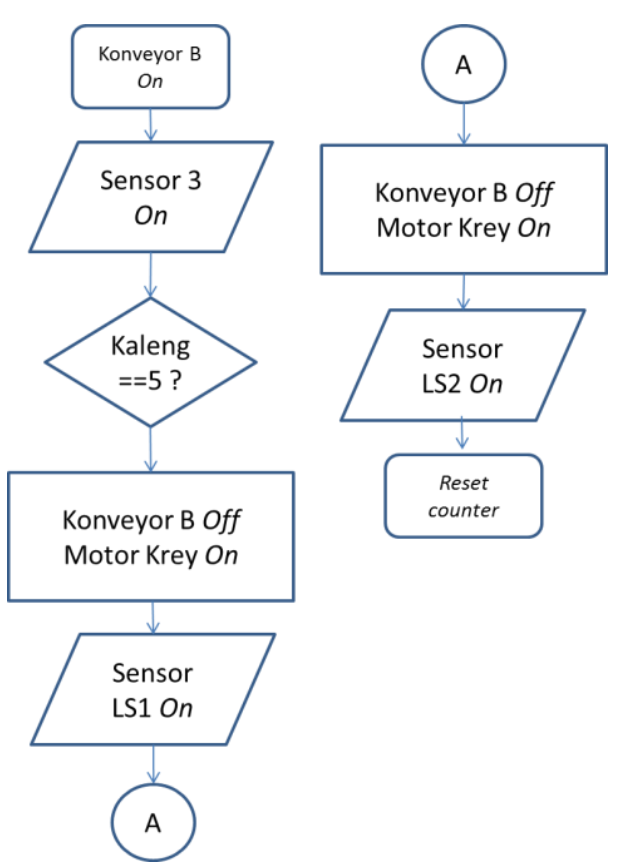

Gambar 5. Blok Diagram Proses Pengepakan Kaleng Kemasan ke dalam Box

Ketika ada beberapa kaleng yang dalam kasus ini dibatasi 5 kaleng telah melewati dan memenuhi syarat counter sensor 3, maka sensor 3 akan aktif. Aktifnya sensor 3 akan mengakibatkan konveyor $B$ akan mati dan berhenti membawa kaleng kemasan pada motor krey. Motor krey akan mencengkram kaleng kemasan dan menjatuhkannya ke dalam box yang ditandai dengan aktifnya sensor LS1, yang kemudian mematikan motor krey. Setelah itu box yang sudah berisi kaleng kemasan akan dibawa oleh konveyor C untuk di-packing nantinya hingga menyentuh sensor LS2. Dengan aktifnya sensor LS2, konveyor $\mathrm{C}$ akan mati dan me-reset counter pada sensor 3 dan mengulangi proses yang sama.

Proses pengepakan kaleng kemasan ke dalam box dapat dilihat pada timing diagram pada Gambar 8 yang menyajikan alur proses setiap sensor dan aktuator yang bekerja pada proses ini. 


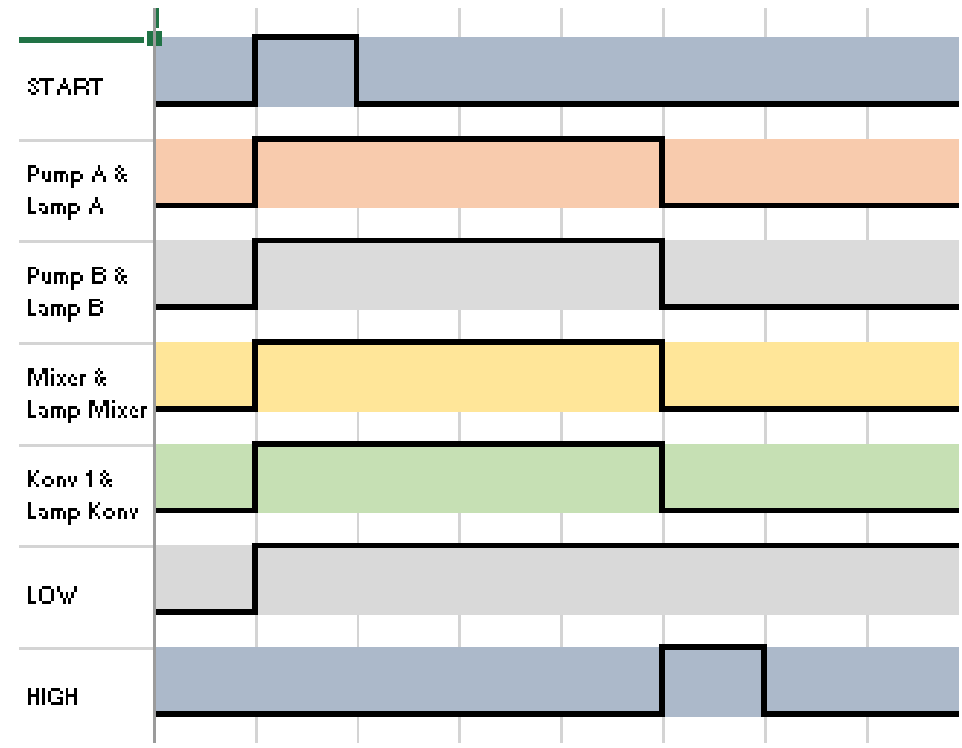

Gambar 6. Timing Diagram Proses Pembuatan Adonan Cat

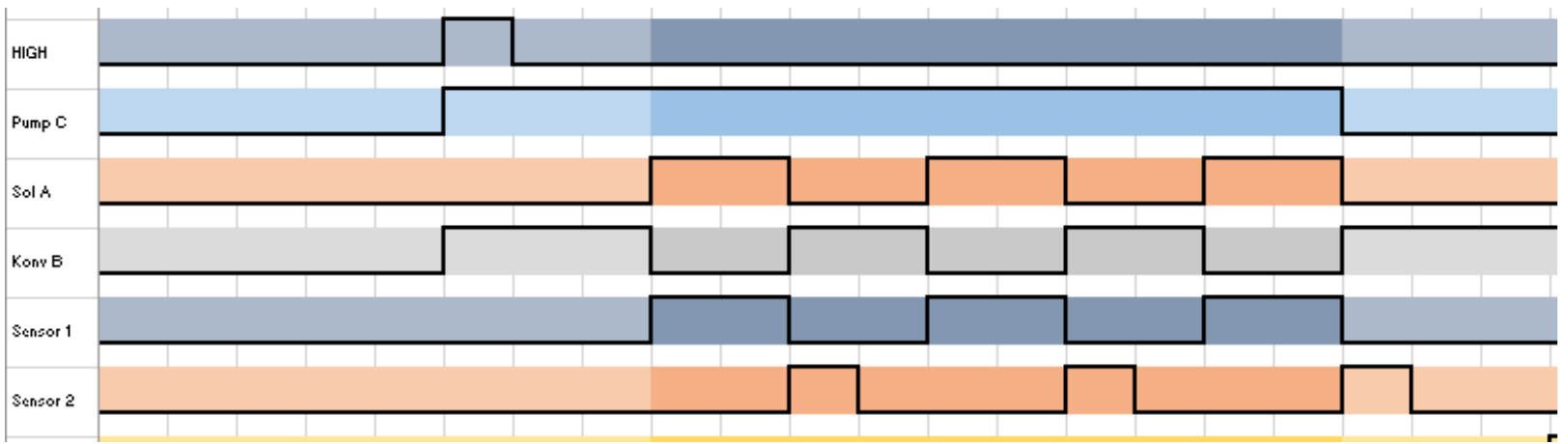

Gambar 7. Timing Diagram Proses Pengisian Cat dalam kaleng

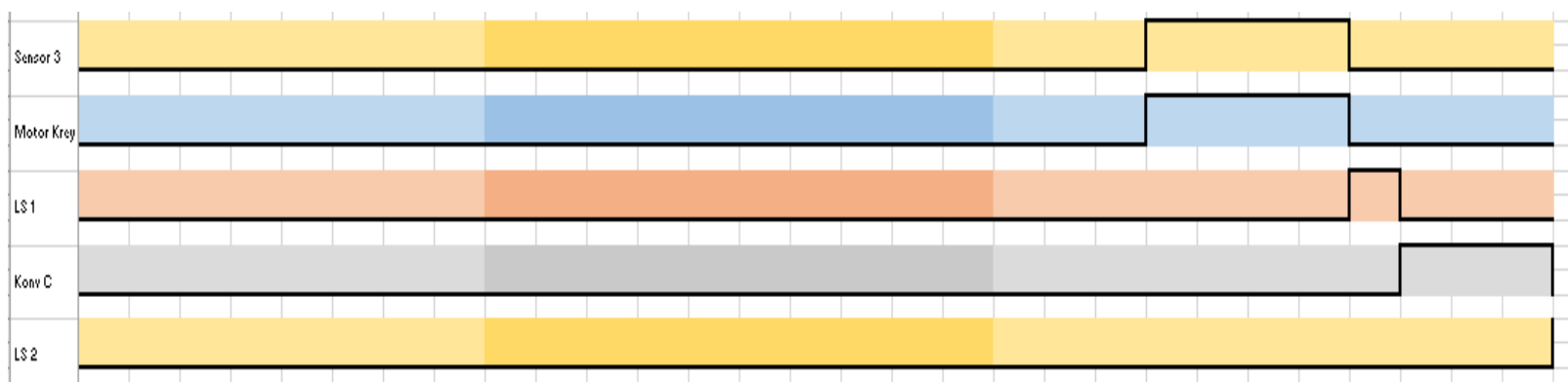

Gambar 8. Timing Diagram Proses Pengepakan Kaleng Kemasan ke dalam Box

\section{IMPLEMENTASI DAN PEMBAHASAN}

Secara garis besar dalam pembuatan diagram ladder untuk otomatisasi proses produksi cat terdapat tiga subprogram, yaitu program pompa air disajikan pada Gambar 9, program kontrol disajikan pada Gambar 10 dan program keluaran pada Gambar 11.
Sebelum membuat program diagram ladder, sangat penting untuk menentukan konfigurasi alamat input dan output seperti yang disajikan pada Tabel 1 yang nantinya akan bertindak sebagai sensor dan actuator. 


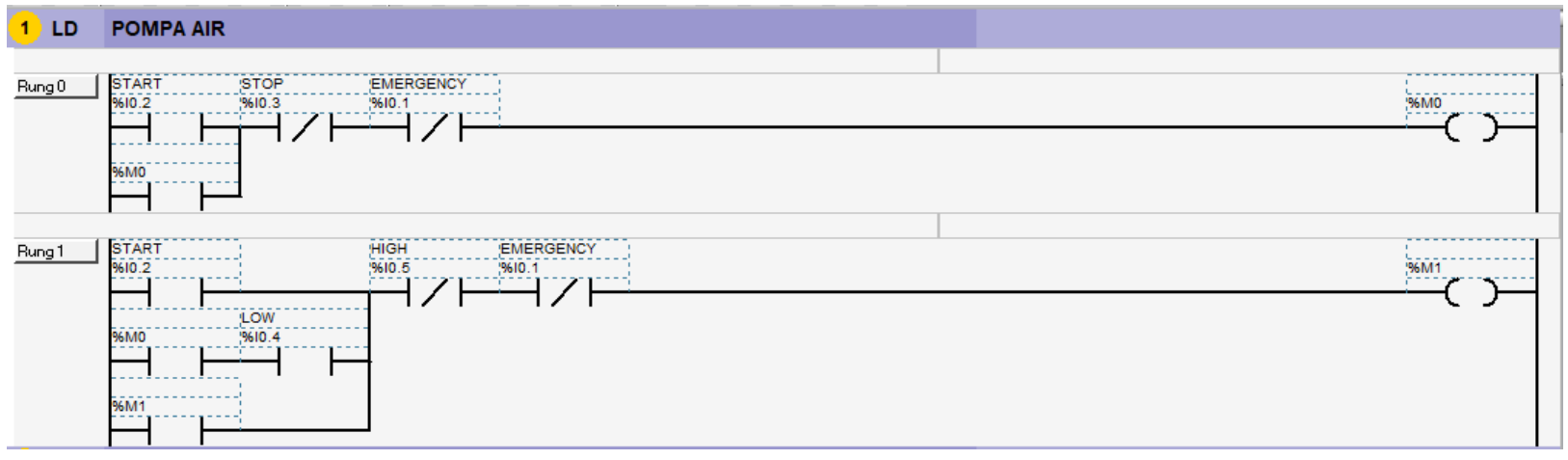

Gambar 9. Ladder Diagram Pompa Air

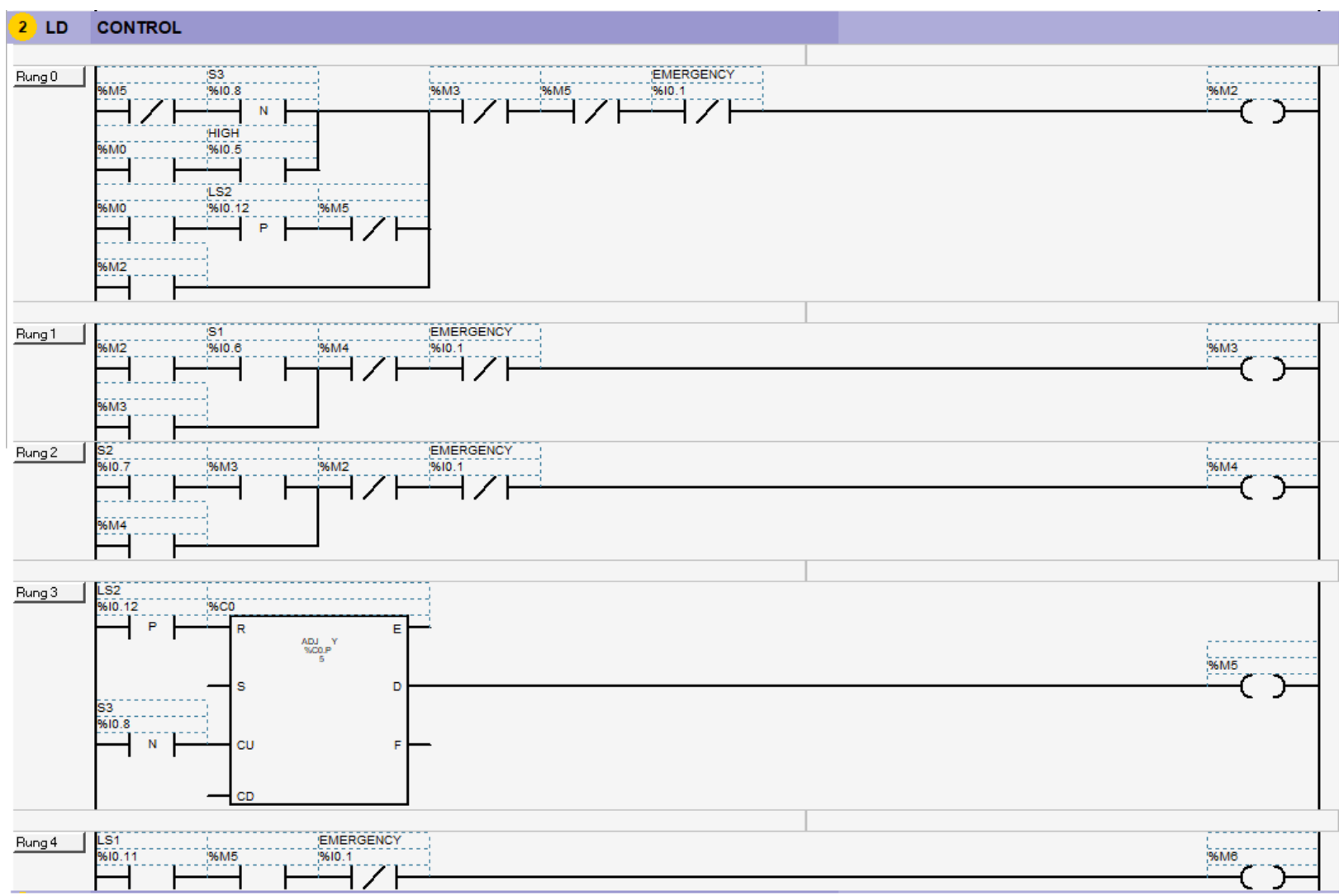

Gambar 10. Ladder Diagram Proses Utama 


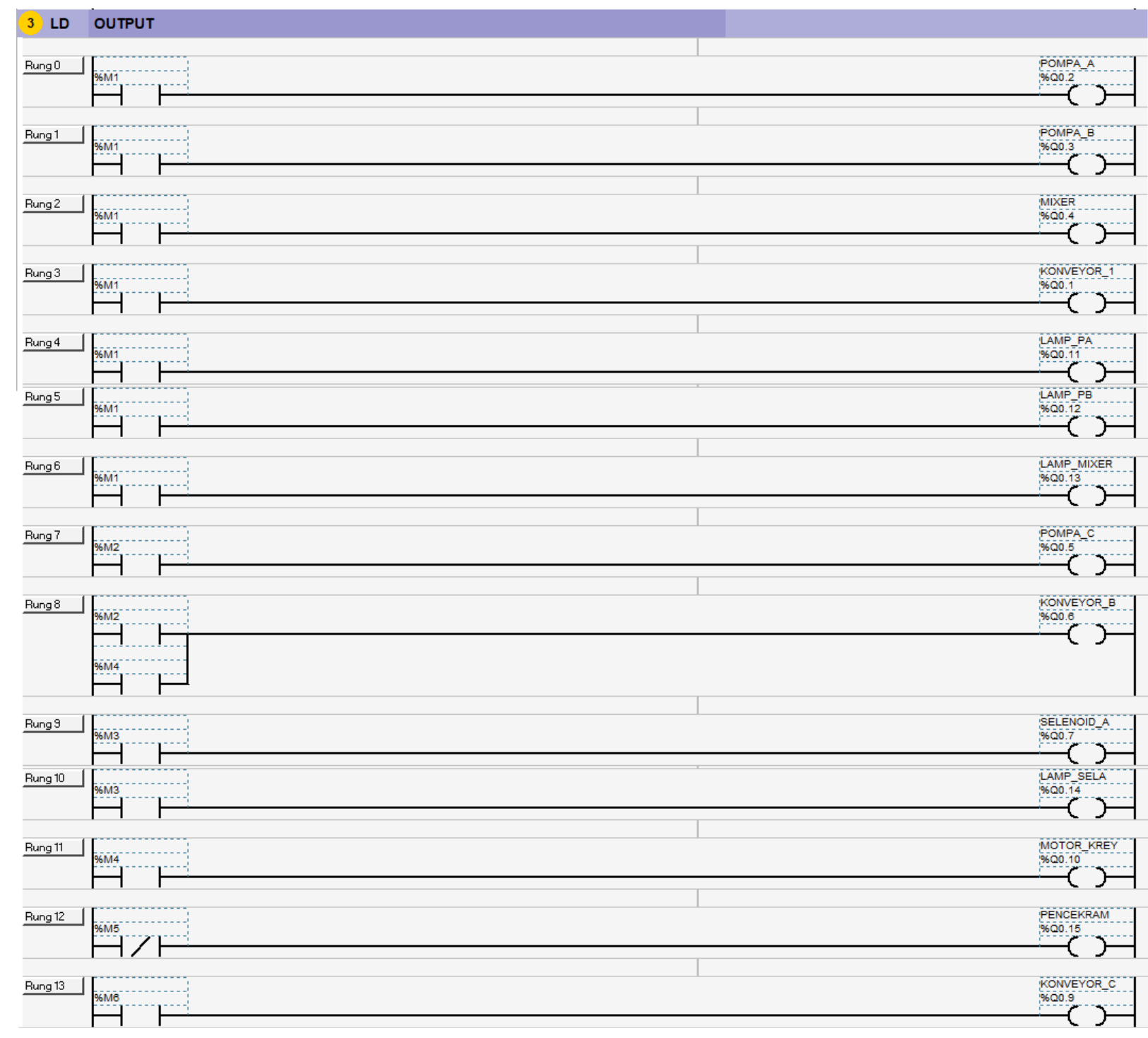

\section{Gambar 11. Ladder Diagram Output}

Pada rung 0 saat tombol start (i0.2 normally open) ditekan maka memori M0 akan aktif dan mengaktifkan kondisi latching memori M0. Disaat yang bersamaan tombol start juga mengaktifkan memori M1 dan mengaktifkan kondisi latching M1 yang nantinya akan mengaktifkan konveyor 1, mixer, dan pompa 1 hingga cairan cat penuh. Saat sensor HIGH (i0.1 normally close) aktif maka M1 akan mati dan menghentikan proses pengadukan cat.

Pada subprogram kontrol, proses yang dilakukan adalah melakukan pengisian kaleng cat hingga penuh dan memasukan 5 buah kaleng cat ke dalam kardus. Memori M2 adalah proses konveyor 2 berjalan membawa kaleng cat ke tempat pengisian. Saat S1 terpenuhi (kaleng sampai ditempat pengisian) maka M3 akan aktif dan menonaktifkan M2. M3 digunakan untuk melakukan proses pengisian cat. Saat kaleng penuh (S2 aktif) maka pengisian akan selesai dan meletakan kaleng cat ke motor krey, proses ini akan dilakukan selama 5 kali (dengan fungsi counter pada rung 3 . Setelah 5 kaleng sudah diisi maka motor krey akan aktif dan menjatuhkan kaleng cat ke dalam box. Ketika L1 terpenuhi (kaleng sudah masuk box) maka M6 akan aktif untuk menjalankan konveyor 3 . Saat box sudah melewati konveyor 3 maka LS2 akan mereset counter 0 dan akan mengulangi proses pengisian kaleng cat. 
Tabel 1. Konfigurasi Alamat Input dan Output Ladder Diagram.

\begin{tabular}{llll}
\hline & Input & \multicolumn{1}{c}{ Output } \\
\hline \multicolumn{1}{c}{ Detail } & \multicolumn{1}{c}{ Address } & \multicolumn{1}{c}{ Detail } & \multicolumn{1}{c}{ Address } \\
\hline EMERGENCY & $\% 10.1$ & KONVEYOR_1 & $\% Q 0.1$ \\
START & $\% 10.2$ & POMPA_A & $\% Q 0.2$ \\
STOP & $\% 10.3$ & POMPA_B & $\% Q 0.3$ \\
LOW & $\% 10.4$ & MIXER & $\% Q 0.4$ \\
HIGH & $\% 10.5$ & POMPA_C & $\% Q 0.5$ \\
S1 & $\% 10.6$ & KONVEYOR_B & $\% Q 0.6$ \\
S2 & $\% 10.7$ & SELENOID_A & $\% Q 0.7$ \\
S3 & $\% 10.8$ & SELENOID_B & $\% Q 0.8$ \\
S4 & $\% 10.9$ & KONVEYOR_C & $\% Q 0.9$ \\
S5 & $\% 10.10$ & MOTOR_KREY & $\% Q 0.10$ \\
LS1 & $\% 10.11$ & LAMP_PA & $\% Q 0.12$ \\
LS2 & $\% 10.12$ & LAMP_PB & $\% Q 0.12$ \\
& & LAMP_MIXER & $\% Q 0.13$ \\
& & LAMP_SELENOID & $\% Q 0.14$ \\
\hline
\end{tabular}

Dalam pemrograman PLC tidak diperbolehkan menggunakan output yang sama lebih dari satu (Darminto, D., Facta, M., \& Setiawan, 2011). Oleh karena itu perlu dibuat subprogram output. Dalam subprogram ini akan berisi semua output yang digunakan, input yang digunakan untuk mengaktifkan output adalah memorimemori yang ada dalam subprogram pompa air dan subprogram kontrol. Sehingga dengan demikian 1 buah output akan bisa diaktifkan dengan lebih dari satu input memori.

\section{SIMPULAN}

Dalam otomatisasi proses produksi cat terdapat tiga proses utama yaitu, proses pembuatan adonan cat, proses pengisian cat dalam kaleng kemasan, dan proses pengepakan kaleng kemasan ke dalam box. Pada makalah ini, simulasi sistem otomasi produksi cat menggunakan software Twido Suite TWDLMDA20DTK. Simulasi bertujuan untuk meminimalkan kesalahan dalam merancang sistem sehingga dapat menghemat waktu. Hasil yang diperoleh dari simulasi bahwa sistem telah berjalan dengan baik dan sesuai dengan seharusnya.

\section{UCAPAN TERIMAKASIH}

Penulis mengucapkan terima kasih kepada Laboratorium Instrumentasi Kendali Diploma Teknik Elektro Sekolah Vokasi
Universitas Gadja Mada atas dukungan dan fasilitas yang telah diberikan.

\section{DAFTAR PUSTAKA}

Antono, D. (2012). Mesin Penjual Minuman Kaleng dengan Kendali Logika Terprogram yang Dioperasikan dengan Layar Sentuh ( NT 21 S ), 1625.

Ardiansyah, H., Taryana, N., \& Nataliana, D. (2013). Perancangan Simulator Sistem Pengepakan dan Penyortiran Barang berbasis PLC Twido, 1(4), 373-385.

Barrett, M. (2008). The Design of a Portable Programmable Logic Controller (PLC) Training System for Use outside of the Automation Laboratory. International Symposium for Engineering Education, 1-5.

Bolton, W. (2004). Programmable Logic Controller (PLC). (I. Harmeni, Ed.) (edisi keti). Erlangga.

Darminto, D., Facta, M., \& Setiawan, I. (2011). Programable Logic Controler ), $1-7$.

Electric, S. (2006). Twido Programmable Controller (Programmab). French: Schneider Electric.

Janotha, Z. (2014). Perencanaan Aplikasi Programmable Logic Controller (PIC) Omron Cpm1a Sebagai Pusat Sistem Pemompaan Rpa I Dan Rpa li Di Pt 
Pertamina (Persero) Ru lii PlajuSungai Gerong (Doctoral D). Politeknik Negeri Sriwijaya.

Johnson, D. (2007). Programmable logic controllers. Control Engineering.

Nurseto, T. (2011). Membuat Media

Pembelajaran yang Menarik - Tejo Nurseto. Ekonomi \& Pendidikan, 8, 19-35.

O.Boucher, T. (2012). Programmable Logic.
Computer Automation in

Manufacturing.

Ramadhan, F. (2014). Sistem Kontrol

Seleksi Barang Otomatis Pada Mesin

Stempel Dengan Sistem Elektro-

Pneumatik (Doctoral D). Politeknik Negeri Sriwijaya.

Setiawan, I. (2006). Programmable Logic Controller dan Teknik Perancangan Sistem Kontrol, 1-14. 